\title{
PENGARUHPENGGUNAAN STRATEGI PEMBELAJARAN INQUIRY PADA SISWA KELAS X.AV.2 PADA MATERI KONDENSATOR DI SMK NEGERI 1 WONOASRI
}

\author{
Ihtiari Prastyaningrum ${ }^{1}$, Budi Santoso ${ }^{2}$ \\ ${ }^{1}$ Prodi Pendidikan Teknik Elektro, FPTK, IKIP PGRI Madiun \\ Madiun, 63118, Indonesia \\ ${ }^{2}$ Prodi Pendidikan Teknik Elektro, FPTK, IKIP PGRI Madiun \\ Madiun, 63118, Indonesia \\ Email : ihtiari@ikippgrimadiun.ac.id; santosobudipte@gmail.com
}

\begin{abstract}
ABSTRAK
Penelitian ini bertujuan untuk mengetahui ada atau tidak nya peningkatan prestasi belajar siswa, pada siswa kelas XAV2 Teknik Audio Video Smk Negeri 1 Wonoasri. Setelah menggunakan strategi belajar dengan dengan strategi pembelajaran Inquiry. Penentuan sampel di dalam penelitian ini yaitu pada siswa kelas X AV 2 Smk Negeri 1 Wonoasri dengan jumlah murid 36 anak. Pengumpulan data dilakukan langsung pengamatan pada siswa dan dilakukan dalam 3 siklus, selanjutnya data di analisis menggunakan metode statistik dengan menggunakan rumus interval. Hasil terlihat adanya peningkatan prestasi belajar siswa, setelah menggunakan strategi pembelajaran Iquiry. Dengan demikian strategi pembelajaran Inquiry adalah salah satu metode belajar yang sangat tepat digunakan dalam proses belajar pada mata pelajaran produktif pada siswa kelas XAV 2 SMK Negeri 1 wonoasri.
\end{abstract}

Kata kunci: Prestasi Belajar, Inquiry, Kondensator

\section{Pendahuluan}

Peningkatan kualitas sumber daya manusia merupakan persyaratan mutlak untuk mencapai tujuan pembangunan. Salah satu wahana untuk meningkatkan kualitas SDM tersebut adalah pendidikan, sehingga kualitas pendidikan harus senantiasa ditingkatkan. Kualitas kehidupan bangsa sangat ditentukan oleh faktor pendidikan. Oleh karena itu tindakan pendidikan selalu bersifat aktif dan terencana, makaa pendidikan merupakan suatu perbuatan atau tindakan sadar agar terjadi perubahan sikap dan tata laku yang diharapkan yaitu manusia yang cerdas, terampil, mandiri, berdisiplin dan berakhlak mulia (Zainudin 2008; 2).

Pada era global seperti saat ini, Sumber Daya Manusia (SDM) menjadi unsur penentu dalam kelangsungan hidup manusia. Untuk menghadapi tantangan pada masa mendatang, pendidikan nasional dilaksanakan dengan tujuan meningkatkan kualitas manusia Indonesia seutuhnya. Upaya meningkatkan kualitas manusia Indonesia seutuhnya tidak hanya menjadi tugas dan tanggung jawab para pakar, birokrat dan politisi saja, melainkan juga menjadi tugas dan tanggung jawab guru dan semua orang yang berkecimpung di bidang pendidikan dan pengajaran. Oleh karena itu dalam kegiatan mengajar ini tentu saja tidak dapat dilakukan sembarangan, tetapi harus menggunakan teori-teori dan prinsipprinsip belajar tertentu agar bisa bertindak secara tepat (Dimyati dan Mudjiono, 1999: 41).

Perubahan dalam meningkatkan mutu dan kualitas pendidikan guru sangat berperan, sebab guru adalah orang kedua setelah orang tua yang bertugas sebagai pentransfer ilmu pengetahuan kepada anak. Untuk itu metode yang dilakukan guru sangat tergantung dari kreatifitas guru itu sendiri dalam menyampaikan isi materi kepada anak didik. Fenomenafenomena tersebut menjadikan tantangan bagi peneliti untuk dapat melakukan suatu 
perubahan dalam proses pembelajaran agar dapat menghasilkan suatu prestasi belajar yang optimal. Perubahan proses pembelajaran tersebut dengan menawarkan suatu strategi pembelajaran inquiry sebagai upaya meningkatkan prestasi belajar siswa Sekolah Menengah Kejuruan.

Inquiry merupakan salah satu komponen dari penerapan pendekatan CTL (Contextual Teaching and Learning), yang berarti menemukan. Menurut Nurhadi (2004: 122) Dalam pembelajaran dengan penemuan/inquiry, siswa didorong untuk belajar sebagian besar melalui keterlibatan aktif dengan konsep-konsep dan prinsip-prinsip, serta guru mendorong siswa untuk memiliki pengalaman dan melakukan percobaan yang memungkinkan mereka menemukan prinsip-prinsip untuk diri mereka sendiri.

Strategi pembelajaran yang lebih memberi hasil yang baik bagi siswa adalah pembelajaran yang banyak melibatkan siswa berpikir, berbicara, berargumentasi dan mengutarakan gagasan-gagasannya ( Tulus, 2004: 77 ).

Berdasarkan fenomena tersebut, peneliti akan melakukan suatu upaya penelitian tindakan pada siswa kelas X.AV.2 Sekolah Menengah Kejuruan Negeri 1 Wonoasri Kabupaten Madiun melalui kegiatan belajar dengan strategi pembelajaran inquiry.

Beberapa alasan peneliti menggunakan pembelajaran inquiry dalam mengajarkan materi pembelajaran produktif Teknik Audio Video dikarenakan model pembelajaran inquiry bertujuan mengembagkan keterampilan intelektual, berpikir kritis, dan mampu memecahkan masalah secara ilmiah.

Sedangkan alasan peneliti memilih mata pelajaran produktif Teknik Audio Video sebagai materi bahan pembelajaran inquiry, karena dalam kurikulum produktif Teknik Audio Video dapat membantu siswa untuk memanfaatkan kesempatan mengembangkan kemampuan dan kemampuan tentang konsep-konsep kondensator.

Dari beberapa alasan diatas maka dapat dirumuskan judul penelitian tindakan kelas."Peningkatan Prestasi Belajar dengan Strategi Pembelajaran Inquiry pada sISwa Kelas X.AV.2 mata Pelajaran Produktif Teknik Audio Video pada Materi Kondensator Di Sekolah Menengah Kejuruan Negeri 1 Wonoasri”.

Berdasarkan pada rumusan masalah tersebut dapat dirumuskan tujuan penelitian yaitu untuk mengetahui penerapan strategi pembelajaran inquiry dalam meningkatkan prestasi belajar mata pelajaran Produktif Teknik Audio Video pada siswa Kelas X.AV.2 Sekolah Menengah Kejuruan Negeri 1 Wonoasri Kabupaten Madiun.

\section{Metode}

Lokasi penelitian ini di Sekolah Menegah Kejuruan Negeri 1Wonoasri. Jl Panglima Sudirman No.1 CarubanMadiun.Penelitian ini tergolong dalam penelitian tindakan kelas Menurut Mills (Wiyono, 2008:1) penelitian tindakan kelas adalah penelitian sistematis yang dilakukan oleh peneliti guru, kepala sekolah atau lainnya tentang situasi belajar mengajar di kelas dengan mengumpulkan informasi tentang praktikpraktik kegiatan sekolah, kegiatan mengajar guru, atau kegiatan belajar siswa dalam rangka untuk memperoleh wawasan, mengembangkan praktikpraktik secara reflektif, serta membawa dampak perubahan positif terhadap sekolah, dan meningkatkan hasil belajar siswa.

Data yang sesuai dengan tujuan penelitian maka penelitian tindakan kelas ini akan dilaksanakan dalam tiga siklus. Masing-masing terdiri dari empat tahapan yaitu perencanaan, pelaksanaan tindakan, pengamatan (observasi), dan refleksi. Dalam penelitian ini dilakukan 3 siklus pembelajaran.

Analisis data dalam penelitian ini dilakukan selama dan setelah pengumpulan data. Hasil pengumpulan data akan dianalisa menurut kategorinya yaitu data tes formatif. Untuk mengetahui adanya peningkatan prestasi belajar siswa, data yang diperoleh dianalisis dengan membandingkan nilai hasil tes formatif pada setiap siklusnya. 
Nilai siswa digunakan rumus :

Nilai Siswa $=\frac{\sum \text { Skor yang diperoleh }}{\sum \text { Skor Maksimal }} \times 100$

Nilai Kriteria Ketuntasan Minimum (KKM) di SMK Negeri 1 Wonoasri adalah 70. Oleh karena itu, peneliti mengharap indikator pencapaian dalam penelitian ini bisa mencapai 75 dari jumlah siswa di SMK Negeri 1 Wonoasri.

\section{Hasil}

Hasil penelitian ini diperoleh dari kegiatan pengamatan dan observasipeneliti selama kegiatan penelitian berlangsung.

Pada siklus I, rencana tindakan dilakukan dengan alokasi waktu 4 x 45 menit. Dan belum menggunakan strategi pembelajaran inquiry/masih menggunakan metode tradisional. Hal ini untuk mengetahui seberapa jauh prestasi siswa dan untuk pengambilan data awal. Pada langkah ini peneliti membuat perencanaan tentang pembelajaran secara menyeluruh yaitu Peneliti mempersiapkan materi pelajaran yang akan diajarkan dalam pelaksanaan tindakan, menyiapkan perangkat pembelajaran diantaranya silabus sesuai dengan kurikulum yang berlaku, Rencana Pelaksanaan Pembelajaran (RPP) dengan metode pembelajaran tradisional dan menyusun soal untuk evaluasi siswa (tes formatif) pada akhir siklus. Peneliti melaksanakan pembelajaran sesuai dengan pada perencanaan, adapun langkah-langkah sebagai berikut:

a. Kegiatan awal yaitu memberikan pengertian masalah tujuan pembelajaran. Apresiasi berisi penjelasan singkat tentang materi yang akan di bahas

b. Kegiatan inti yaitu menyampaikan kepada siswa tentang materi pembahasan yaitu menjelaskan pengertian kondensator dengan menggunakan metode pembelajaran secara tradisional. Setelah peneliti menjelaskan siswa diberi kesempatan untuk bertanya tentang kesulitan yang di hadapi dalam menerima penyampaian materi, dan peneliti akan menjelaskan lagi kesulitan penyampaian materi yang muncul dalam pembelajaran, secara singkat.

c. Penutup atau kegiatan akhir yaitu peneliti memberikan tes evaluasi pada siswa.

Berdasarkan hasil evaluasi belajar dalam kegiatan pada siklus 1 dapat di distribusikan secara frekwensi presentase, Data tersebut didistribusikan berdasarkan perolehan hasil evaluasi belajar setiap individu setelah melakukan serangkaian kegiatan belajar mengajar dengan strategi pembelajaran secara tradisional.

Tabel 1.Distribusi Frekwensi Hasil

Evaluasi Belajar SiswaSiklus 1

\begin{tabular}{cccc}
\hline No & $\begin{array}{c}\text { Interval } \\
\text { Nilai }\end{array}$ & Frekwensi & $\begin{array}{c}\text { Frekwensi } \\
\%\end{array}$ \\
\hline 1 & $87-95$ & 3 & $11 \%$ \\
\hline 2 & $78-86$ & 7 & $22 \%$ \\
\hline 3 & $69-77$ & 9 & $25 \%$ \\
\hline 4 & $60-68$ & 17 & $42 \%$ \\
\hline T o t a 1: & 36 & $100 \%$ \\
\hline
\end{tabular}

Dari frekwensi data tersebut dapat diketahui bahwa siswa yang mencapai kriteria ketuntasan minimum sebanyak 9 siswa, dan siswa yang mendapatkan diatas kriteria ketuntasan minimum adalah sebanyak 10 siswa, dan yang tidak tuntas 17 siswa. Selanjutnya untuk membuktikan keefektifan penggunaan strategi pembelajaran inquiry dalam kegiatan belajar mengajar, peneliti akan melanjutkan pembelajaran pada kegiatan siklus 2 ini.

Pada siklus II, rencana tindakan dilakukan dengan alokasi waktu 4 x 45 menit. dan peneliti sudah menggunakan metode pembelajaran inquiry. Pada langkah ini peneliti membuat perencanaan tentang pembelajaran yaitu Peneliti mempersiapkan materi pelajaran yang akan diajarkan dalam pelaksanaan tindakan, menyiapkan perangkat pembelajaran diantaranya silabus sesuai dengan kurikulum yang berlaku, Rencana Pelaksanaan Pembelajaran (RPP) menggunakan metode peningkatan prestasi 
belajar dengan strategi pembelajaran inquiry, dan perangkat lain sebagai pendukung dalam pembelajaran ini serta menyusun soal untuk evaluasi siswa (tes formatif) pada akhir siklus. Pelaksanaan yang di lakukan adalah melaksanakan rencana pembelajaran sesuai dengan rencana pada perencanaan, adapun langkah-langkahnya adalah sebagai berikut:

a. Kegiatan awal yaitu memberikan pengertian masalah tujuan pembelajaran. Apresiasi berisi penjelasan singkat tentang materi yang akan di bahas.

b. Kegiatan inti yaitu menyampaikan kepada siswa tentang materi pembahasan yaitu menjelaskan pengertian dan prinsip kerja kondensator dengan menggunakan metode peningkatan prestasi belajar dengan strategi pembelajaran inquiry. Peneliti memberikan satu atau lebih pertanyaan kepada peserta didik tentang kondensator.Peneliti membagi peralatan dan perangkat kondensator kepada masing-masing peserta didik dan meminta mereka untuk mengamati cara kerja dari kondensator. Peneliti meminta peserta didik untuk mengerjakan praktek/pengamatan dengan peralatan dan perangkat praktek yang telah disiapkan secara individu. Setelah selesai mengerjakan peneliti memberikan pertanyaan secara lesan kepada peserta didik tentang praktek/pengamatan yang telah mereka dilakukan. Hasil pengamatan yang telah dilakukan sesuai materi bahasan.

c. Peneliti membuat evaluasi dan kesimpulan, peneliti memberikan tugas atau pekerjaan rumah kepada peserta didik, peneliti menutup pelajaran dengan salam.

Berdasarkan hasil evaluasi belajar dalam kegiatan pada siklus 2 dapat di distribusikan secara frekwensi presentase, Data tersebut didistribusikan berdasarkan perolehan hasil evaluasi belajar setiap individu setelah melakukan serangkaian kegiatan belajar mengajar dengan strategi pembelajaran inquiry. Adapun data yang diperoleh sebagai berikut:

Tabel 2. Frekwensi Hasil Evaluasi Belajar SiswaSiklus 2

\begin{tabular}{cccc}
\hline No & $\begin{array}{c}\text { Nilai } \\
\text { interval }\end{array}$ & Frekwensi & $\begin{array}{c}\text { Frekwensi } \\
\%\end{array}$ \\
\hline 1 & $87-95$ & 10 & $28 \%$ \\
\hline 2 & $78-86$ & 12 & $33 \%$ \\
\hline 3 & $69-77$ & 10 & $28 \%$ \\
4 & $60-68$ & 4 & $11 \%$ \\
\hline \multicolumn{2}{c}{ T o t a 1: } & 36 & $100 \%$ \\
\hline
\end{tabular}

Dari frekuensi data tersebut dapat diketahui bahwa siswa yang mencapai kriteria ketuntasan minimum sebanyak 10 siswa, serta yang mendapatkan diatas kriteria ketuntasan minimum adalah sebanyak 22 siswa dan yang tidak tuntas 4 siswa.

Berdasarkan pada kegiatan siklus 2 tersebut, peneliti melakukan refleksi dari hasil kegiatan penelitian sebagai berikut:

1. Terlihat ada peningkatan prestasi belajar siswa dalam mengikuti kegiatan belajar mengajar dibandingkan dengan kegiatan belajar mengajar sebelumnya.

2. Beberapa siswa cepat dalam mempelajari materi pendapat yang disampaikan oleh guru.

3. Beberapa siswa sudah ada keberanian dalam menyampaikan pendapat.

Pada siklus III, rencana tindakan dilakukan dengan alokasi waktu 4 x 45 menit. dan peneliti sudah menggunakan metode peningkatan prestasi belajar dengan strategi pembelajaran inquiry. Pada langkah ini peneliti membuat perencanaan tentang pembelajaran yaitu Peneliti mempersiapkan materi pelajaran yang akan diajarkan dalam pelaksanaan tindakan, menyiapkan perangkat pembelajaran diantaranya silabus sesuai dengan kurikulum yang berlaku, Rencana Pelaksanaan Pembelajaran (RPP) menggunakan metode peningkatan prestasi belajar dengan strategi pembelajaran inquiry, dan perangkat lain sebagai pendukung dalam pembelajaran ini serta 
menyusun soal untuk evaluasi siswa (tes formatif) pada akhir siklus. pelaksanaan yang di lakukan adalah melaksanakan rencana pembelajaran sesuai dengan rencana pada perencanaan, adapun langkah-langkahnya adalah sebagai berikut:

a. Kegiatan awal yaitu peneliti memberikan pengertian masalah tujuan pembelajaran. Apresiasi berisi penjelasan singkat tentang materi yang akan di bahas.

b. Kegiatan inti yaitu peneliti menyampaikan kepada siswa tentang materi pembahasan yaitu menjelaskan pengertian dan prinsip kerja kondensator dengan menggunakan metode pembelajaran secara inquiry.

Peneliti memberikan satu atau lebih pertanyaan kepada peserta didik tentang kondensator. Peneliti membagi peralatan dan perangkat kondensator kepada masingmasing peserta didik dan meminta mereka untuk mengamati cara kerja dari kondensator.

Peneliti meminta peserta didik untuk mengerjakan praktek/pengamatan dengan peralatan dan perangkat praktek yang telah disiapkan secara individu.

Setelah selesai mengerjakan peneliti memberikan pertanyaan secara lesan kepada peserta didik tentang praktek/pengamatan yang telah mereka dilakukan. hasil pengamatan yang telah dilakukan sesuai materi bahasan.

Pada kegiatan penutup, peneliti membuat evaluasi dan kesimpulan, peneliti memberikan tugas atau pekerjaan rumah kepada peserta didik, peneliti menutup pelajaran dengan salam.

Berdasarkan hasil evaluasi belajar dalam kegiatan pada siklus 3 dapat di distribusikan secara frekwensi presentase, Data tersebut didistribusikan berdasarkan perolehan hasil evaluasi belajar setiap individu setelah melakukan serangkaian kegiatan belajar mengajar dengan strategi pembelajaran inquiry. Adapun data yang diperoleh sebagai berikut:

Tabel 3. Frekwensi Hasil Evaluasi Belajar SiswaSiklus 3

\section{No Nilai Frekwensi Frekwensi $\%$}

\begin{tabular}{cccc}
\hline 1 & $91-97$ & 3 & $8 \%$ \\
\hline 2 & $84-90$ & 11 & $31 \%$ \\
\hline 3 & $77-83$ & 16 & $44 \%$ \\
4 & $70-76$ & 6 & $17 \%$ \\
\hline \multicolumn{2}{c}{ T o t a $1:$} & 36 & $100 \%$ \\
\hline
\end{tabular}

Dari frekuensi data tersebut dapat diketahui bahwa siswa yang mencapai kriteria ketuntasan minimum sebanyak 6 siswa, serta yang mendapatkan diatas kriteria ketuntasan minimum adalah sebanyak 30 siswa dan yang tidak tuntas tidak ada.

Berdasarkan pada kegiatan siklus 3 tersebut, peneliti melakukan refleksi dari hasil kegiatan penelitian sebagai berikut:

1. Terlihat ada peningkatan prestasi belajar siswa dalam mengikuti kegiatan belajar mengajar dibandingkan dengan kegiatan belajar mengajar sebelumnya.

2. Sebagian besar siswa lebih cepat dan tanggap dalam mempelajari materi yang disampaikan oleh peneliti.

3. Sebagian besar siswa sudah ada keberanian dalam menyampaikan pendapat.

4. Beberapa siswa lebih agresif dalam memberikan tanggapan pada materi yang diberikan oleh peneliti

Berdasarkan data pengamatan dan obeservasi peneliti selama kegiatan penelitian, siswa dalam kegiatan belajar dengan strategi pembelajaran inquiry menunjukkan ada peningkatan dibandingkan dengan strategi sebelumnya/tradisional. Hal ini dapat dilihat dari data yang didapatkan oleh peneliti, dan hasil belajar siswa dalam kegiatan belajar mengajar menunjukkan mulai meningkat.

Berdasarkan rekapitulasi hasil evaluasi, siswa dalam mengikuti kegiatan belajar tersebut menunjukkan prestasi belajar siswa semakin meningkat dengan strategi 
pembelajaran inquiry. Sebab dengan pembelajaran inquiry, semua siswa dapat melakukan aktivitas dalam kegiatan belajar secara penuh dalam upaya meningkatkan tujuan pembelajaran yang optimal.

\section{Pembahasan}

Berdasarkan tabel perbandingan diatas bahwa prestasi belajar siswa dengan menggunakan strategi pembelajaran inquiry menunjukan hasil positif, hal ini membuktikan bahwa dengan strategi ini prestasi belajar siswa bisa didapat dengan baik sehingga mempengaruhi hasil belajar yang didapatkan. Peningkatan prestasi belajar siswa ini menunjukan bahwa prestasi belajar dipengaruhi oleh strategi belajar yang diberikan oleh guru. Bagaimana guru dapat meningkatkan minat siswa dalam belajar, maka strategi yang cocok harus diterapkan oleh guru tersebut.

\section{Kesimpulan}

Berdasarkan pada pembahasan kegiatan penelitian tindakan yang telah dilakukan oleh peneliti, maka dapat disimpulkan bahwa Strategi pembelajaran dengan menggunakan strategi pembelajaran Inquiry dapat meningkatkan prestasi belajar siswa Kelas X.AV2 SMKN 1 Wonoasri Kabupaten Madiun pada mata pelajaran Produktif Teknik Audio Video Materi Pembelajaran Kondensator.

\section{Daftar Pustaka}

Djamarah, Syaiful Bahri. 2002. Psikologi Belajar. PT Rineka Cipta, Jakarta.

Dimyati dan Mudjiono. 1999. Belajar dan Pembelajaran. Penerbit Bineka Cipta: Jakarta.

Hadi, Sutrisno. 2001. Statistik Jilid 1. Penerbit ANDI Yogyakarta.

Hamalik, Oemar. 2001. Proses Belajar Mengajar. PT Bumi Aksara, Jakarta.

Hawadi, Reni Akbar. 2004. Akselerasi. PT Grasindo Anggota IkapiJakarta.

Mulyasa, E. 2005. Implementasi Kurikulum 2004. PT Remaja Rosdakarya Bandung.

Mustaqim dan Abdul Wahib. 2010. Psikologi Pendidikan. PT Rineka Cipta: Jakarta.
Nurhadi. 2004. Kurikulum 2004. PT Grasindo Anggota IKAPI, Jakarta.

Slameto. 2003. Belajar dan Faktor - faktor yang mempengaruhi nya. PT Rineka Cipta Jakarta.

Tu'u, T.S. Th.. 2004. Peran Disiplin pada perilaku dan prestasi siswa. PT Gramedia Widia sarana Jakarta.

Wiyono, Bambang Budi. 2008. Penelitian Tindakan Kelas dan Penulisan Karya Ilmiah. PenerbitUniversitas Negeri Malang.

Zain, Aswan. 2010. Strategi Belajar Mengajar. PT Rineka Cipta, Jakarta.

Zainudin, M. 2008. Reformasi Pendidikan. Penerbit Pustaka Pelajar. 